\title{
The impact of sex and BMI on the clinical course of COPD and bronchial asthma
}

\author{
KRZYSZTOF WYTRYCHOWSKIㄹ, A-F, ANNA HANS-WYTRYCHOWSKA², A-F
}

${ }^{1}$ Department and Clinic of Internal Medicine and Allergology, Medical University of Wroclaw

${ }^{2}$ Department of Family Medicine, Medical University of Wroclaw

A - Study Design, B - Data Collection, C - Statistical Analysis, D - Data Interpretation, E - Manuscript Preparation, $\mathbf{F}$ - Literature Search, $\mathbf{G}$ - Funds Collection

Summary Background. Bronchial asthma is a heterogeneous disease, and is one phenotype of asthma with obesity. Chronic obstructive pulmonary disease is the fourth most frequent cause of death in the world.

Objectives. The aim of the study was to assess the influence of BMI and sex on the clinical course of uncontrolled asthma and COPD with moderate to severe airflow limitation.

Material and methods. The study was performed on 2 groups. Group A: 72 adults suffering from asthma (38 F - females, 34 $\mathrm{M}$ - males) with at least 1 exacerbation requiring treatment with systemic corticosteroids in the year before the study. Group B: 79 patients (34 F, $45 \mathrm{M}$ ) with COPD Grades 2 and 3 according to GOLD. Data including age, gender, BMI, disease duration, treatment, concomitant diseases, pack-years, and number of exacerbations in the last year were collected. Asthma Control Questionnaire scores in group A and COPD Assessment Test scores in group B were collected. Pulmonary function tests were performed in both groups.

Results. There were no differences between females and males in the analyzed variables in both groups. Obese patients (BMI $\left.>30.0 \mathrm{~kg} / \mathrm{m}^{2}\right)$ were selected for analysis from group $A(18 \mathrm{~F}, 10 \mathrm{M})$ and from group $B(13 \mathrm{~F}, 16 \mathrm{M})$. In group A, the number of exacerbations was significantly lower in males $(M 1.3$ vs. $F 1.9 ; p=0.01)$. In group $B$ the age of obese patients was higher than in patients with $\mathrm{BMI} \leq 30.0$ (68.3 vs. 62.5; $p=0.002)$.

Conclusion. Poorer control of asthma in obese patients was associated with the female gender. Age is a risk factor for obesity development in patients with COPD.

Key words: obesity, gender, COPD, bronchial asthma.

Fam Med Prim Care Rev 2016; 18(3): 368-372

\section{Background}

Bronchial asthma is a heterogeneous disease. There are many phenotypes of this condition based on the clinical course, demography, and pathophysiology. One of them is asthma with obesity. Based on American data, 25.7 million people suffer from bronchial asthma in the USA, and $35.7 \%$ of the general American population are obese [1]. WHO estimates that 300000 deaths per year are directly related to obesity [2, 3].

Obesity is known to be a risk factor for asthma, and comorbidity significantly worsens its course. Severe asthma is one of the phenotypes that often requires systemic administration of corticosteroids (SCS). The drugs and limitation of physical activity lead to an increase in body weight [4]. The influence of obesity on asthma is complex. Obesity mechanically impairs breathing, leading to mild restriction, and moderates the immune system, which results in systemic inflammation $[5,6]$. In obese people sleep apnea and esophageal reflux are more common [7]. The comparison of two populations of patients suffering from asthma: obese and of normal weight, revealed that in the first group there are more women, the quality of life is lower, asthma exacerbations are more frequent, and the response to inhaled corticosteroids is poorer, which results in a higher demand for corticosteroids [8].

Chronic obstructive pulmonary disease (COPD) is the fourth most common mortality cause in the world, and in recent years the number of deaths related to COPD has increased [9]. COPD is a result of the interaction between genes and the environment. Tobacco smoke is the major environmental factor, although other occupational and genetic factors are also important. One of the causes of the increase in COPD morbidity is the increase in the average lifespan observed in many countries [9]. A couple of decades ago most patients were men. At present, the percentage of men and women affected by this condition is more or less even. The increase in tobacco consumption in women is the main cause of this situation, although there are also reports on the higher toxic potential of tobacco smoke in women [10].

There are two basic phenotypes of COPD. The first one concerns young patients with a severe course of the disease, low cardiovascular risk, low BMI, increasing respiratory failure, and with poor prognosis regarding long-time survival. The second phenotype regards older obese patients with cardiovascular and metabolic diseases [11]. Some publications also distinguish the phenotype of high anxiety and depression. This phenotype is found mostly in women [12]. The influence of obesity on COPS course depends on the stage of respiratory failure. In patients with mild and intermediate COPD stage, overweight states and obesity correlate with higher risk of mortality. In severe cases obesity decreases the risk of mortality (the so-called obesity paradox) [13]. In obese patients, the annual drop in $\mathrm{FEV}_{1}$ is lower than in patients with normal BMI, whereas this phenomenon is not observed among women. 


\section{Objectives}

The study aimed to evaluate the influence of body mass index (BMI) and sex on the clinical course of uncontrolled asthma and COPD with moderate or severe respiratory restriction.

\section{Material and methods}

The studies were performed in two groups of patients. Group A consisted of 72 adults (38 women and 34 men) with bronchial asthma diagnosed and treated at least 18 months before enrollment into the study, with at least one exacerbation that required the systemic administration of corticosteroids within 12 months before enrollment. All patients received treatment grade 4 according to the GINA: at least two disease-controlling drugs (inhaled corticosteroids, long-acting$-\mathrm{B}_{2}$-agonist, and an antileukotriene medication). The following parameters were assessed: age, BMI, disease duration, concomitant diseases, and the number of asthma exacerbations in the last year. The patients filled in the Asthma Control Questionnaire (ACQ). The possible scores range from 0 to 6 (the more points the patient got, the worse the asthma control is). A score between 0-0.75 - well-controlled asthma, 0.75-1.5 - intermediate, and above 1.5 - uncontrolled asthma [15]. Every patient underwent spirometry. Forced expiratory volume in 1 second $\left(\mathrm{FEV}_{1}\right)$ presented as a percentage of the normal value was used in order to assess respiratory function.

Group B consisted of 79 adults ( 34 women and 45 men) diagnosed with COPD, and chronically treated on its account since at least 18 months before enrollment to the study. The patients presented moderate $\left(50 \% \leq \mathrm{FEV}_{1} \leq 80 \%\right.$ of normal) and severe $\left(30 \% \leq \mathrm{FEV}_{1} \leq 50 \%\right.$ of normal) respiratory restriction, which corresponded with grades 2 and 3 of the GOLD score.
All patients in group $B$ received at least two drugs chronically (inhaled corticosteroid, long-acting $\mathrm{B}_{2}$-agonist, longacting anticholinergic, and theophylline). The following parameters were assessed: age, BMI, disease duration, concomitant diseases, pack-years, and number of asthma exacerbations in the last year. The patients filled in the COPD assessment test (CAT), which referred to 8 different issues, 5 points for each (the more points the patient gets, the worse the asthma control is). Spirometry was performed in every patient.

The general characteristics of the evaluated patients are presented in Tables 1 (group A) and 2 (group B). In both groups, no statically significant correlation was found between women and men regarding the analyzed parameters $(p>0.05)$.

Group A1, comprising 28 obese patients with BMI > 30 (18 women and 10 men), was separated from group A. Group B1, comprising 29 obese patients (13 women and 16 men), was separated from group B. Statistical analysis was performed with STATISTICA v. 12 (StatSoft, Inc. Tulsa, USA) and EXCEL spreadsheet. Normal distribution was proved for quantitative parameters using the Kolmogorov-Smirnov test with Lilliefors correction and the Shapiro-Wilk test. In the evaluated population all analyzed quantitative variables, such as: age, BMI, asthma duration, $\mathrm{ACQ}$, and $\mathrm{FEV}_{1}$, presented normal distribution. Means (M), standard deviations $(\mathrm{SD})$, minimum value ( $\mathrm{min}$ ), and maximum value (max) were calculated for all measurable parameters. The $t$-Student test was used to determine the statistical significance of differences in means between the two groups (women vs. men) for parameters presenting normal distribution and homogeneity of variance. Homogeneity of variance of quantitative variables in the compared groups was verified using Bartlett's test. The value of $p<0.05$ was considered statistically significant.

\begin{tabular}{|c|c|c|c|c|}
\hline \multirow[t]{2}{*}{ Parameter } & Total & Women & Men & \multirow{2}{*}{$\begin{array}{l}M \text { vs. W } \\
p\end{array}$} \\
\hline & $n=72$ & $n=38$ & $n=34$ & \\
\hline $\begin{array}{l}\text { Age (years) } \\
M \pm S D\end{array}$ & $51.7 \pm 12.4$ & $51.8 \pm 13.4$ & $51.6 \pm 11.3$ & 0.961 \\
\hline $\begin{array}{l}\mathrm{BMI}\left(\mathrm{kg} / \mathrm{m}^{2}\right) \\
\mathrm{M} \pm \mathrm{SD}\end{array}$ & $28.6 \pm 5.0$ & $29.2 \pm 5.4$ & $27.8 \pm 4.5$ & 0.252 \\
\hline $\begin{array}{l}\text { Asthma duration }<\mathrm{t} 0 />\text { (years) } \\
\mathrm{M} \pm \mathrm{SD}\end{array}$ & $19.6 \pm 11$ & $17.9 \pm 10$ & $21.6 \pm 12$ & 0.154 \\
\hline $\begin{array}{l}\text { Asthma exacerbation (number/year) } \\
\qquad \mathrm{S} \pm \mathrm{SD}\end{array}$ & $1,5 \pm 1$ & $1.6 \pm 1$ & $1.4 \pm 1$ & 0.391 \\
\hline $\begin{array}{c}\mathrm{ACQ} \text { (points) } \\
\mathrm{M} \pm \mathrm{SD}\end{array}$ & $2.6 \pm 0.7$ & $2.6 \pm 0.7$ & $2.6 \pm 0.8$ & 0.917 \\
\hline $\begin{array}{l}\mathrm{FEV}_{1}(\% \text { of normal }) \\
\mathrm{M} \pm \mathrm{SD}\end{array}$ & $65.2 \pm 16.1$ & $64.3 \pm 17.6$ & $66.1 \pm 14.5$ & 0.624 \\
\hline
\end{tabular}

\begin{tabular}{|c|c|c|c|c|}
\hline \multirow[t]{2}{*}{ Parameter } & Total & Women & Men & \multirow{2}{*}{$\begin{array}{l}\text { W vs. M } \\
p\end{array}$} \\
\hline & $n=79$ & $n=34$ & $n=45$ & \\
\hline $\begin{array}{l}\text { Age (years) } \\
M \pm S D\end{array}$ & $66.2 \pm 8.3$ & $66.9 \pm 7.2$ & $65.6 \pm 9.0$ & 0.961 \\
\hline $\begin{array}{l}\mathrm{BMI}\left(\mathrm{kg} / \mathrm{m}^{2}\right) \\
\mathrm{M} \pm \mathrm{SD}\end{array}$ & $28.1 \pm 5.2$ & $27.2 \pm 6.2$ & $28.7 \pm 4.2$ & 0.252 \\
\hline $\begin{array}{l}\text { COPD duration (years) } \\
\mathrm{M} \pm \mathrm{SD}\end{array}$ & $8.7 \pm 6.5$ & $9.3 \pm 7.3$ & $8.3 \pm 5.8$ & 0.154 \\
\hline $\begin{array}{l}\text { COPD exacerbation (number/year) } \\
M \pm S D\end{array}$ & $1.1 \pm 0.7$ & $1.2 \pm 0.8$ & $1.0 \pm 0.7$ & 0.391 \\
\hline
\end{tabular}




\begin{tabular}{|c|c|c|c|c|}
\hline \multirow[t]{2}{*}{ Parameter } & Total & Women & Men & \multirow{2}{*}{$\begin{array}{l}\text { W vs. M } \\
p\end{array}$} \\
\hline & $n=79$ & $n=34$ & $n=45$ & \\
\hline $\begin{array}{c}\text { Pack-year } \\
M \pm S D\end{array}$ & $43.4 \pm 15.9$ & $42.3 \pm 12.8$ & $44.2 \pm 18.0$ & 0.587 \\
\hline $\begin{array}{l}\text { CAT (points) } \\
M \pm S D\end{array}$ & $19.7 \pm 6.3$ & $19.1 \pm 5.6$ & $20.1 \pm 6.7$ & 0.493 \\
\hline $\begin{array}{l}\mathrm{FEV}_{1}(\% \text { of normal }) \\
\mathrm{M} \pm \mathrm{SD}\end{array}$ & $54.0 \pm 13.2$ & $53.7 \pm 12.5$ & $54.2 \pm 13.9$ & 0.878 \\
\hline
\end{tabular}

\section{Results}

In groups A1 and B1 there were no differences between men and women regarding the analyzed parameters (Tabs. 3 and 4). The comparison of group A1 with group A with $\mathrm{BMI} \leq 30$ (Tab. 5) detected a significant difference in asthma exacerbations within the last 12 months requiring the sys- temic administration of corticosteroids (group A 1.3, \pm 0.7 vs. $1.9, \pm 1.1 ; p=0.01)$. The comparison of the patients from group B1 and group B with BMI $\leq 30$ (Tab. 6) proved that the obese patients (group B1) were older $(68.3, \pm 7.8$ vs. $62.5 \pm$ $7.9 ; p=0.002)$. There were no differences in the prevalence of concomitant diseases between women and men in the chosen groups.

\begin{tabular}{|c|c|c|c|c|}
\hline \multirow[t]{2}{*}{ Parameter } & Total & Women & Men & \multirow{2}{*}{$\begin{array}{l}M \text { vs. W } \\
p\end{array}$} \\
\hline & $n=28$ & $n=18$ & $n=10$ & \\
\hline $\begin{array}{l}\text { Age (years) } \\
M \pm S D\end{array}$ & $52.3 \pm 12.8$ & $53.5 \pm 12.8$ & $50.2 \pm 13.2$ & 0.525 \\
\hline $\begin{array}{l}\mathrm{BMI}\left(\mathrm{kg} / \mathrm{m}^{2}\right) \\
\mathrm{M} \pm \mathrm{SD}\end{array}$ & $33.6 \pm 3.4$ & $33.7 \pm 3.6$ & $33.3 \pm 3.2$ & 0.768 \\
\hline $\begin{array}{l}\text { Asthma duration (years) } \\
M \pm S D\end{array}$ & $19.1 \pm 9.3$ & $18.8 \pm 8.7$ & $19.6 \pm 10.7$ & 0.827 \\
\hline $\begin{array}{l}\text { Asthma exacerbation (number/year) } \\
\quad M \pm S D\end{array}$ & $1.9 \pm 1.1$ & $1.9 \pm 1.3$ & $1.8 \pm 0.9$ & 0.753 \\
\hline $\begin{array}{l}\text { ACQ (points) } \\
\mathrm{M} \pm \mathrm{SD}\end{array}$ & $2.5 \pm 0.5$ & $2.6 \pm 0.6$ & $2.5 \pm 0.4$ & 0.618 \\
\hline $\begin{array}{l}\mathrm{FEV}_{1}(\% \text { of normal }) \\
\mathrm{M} \pm \mathrm{SD}\end{array}$ & $63.6 \pm 15.8$ & $62.9 \pm 17.6$ & $64.9 \pm 12.7$ & 0.761 \\
\hline
\end{tabular}

\begin{tabular}{|c|c|c|c|c|}
\hline \multirow[t]{2}{*}{ Parameter } & Total & Women & Men & \multirow{2}{*}{$\begin{array}{l}\text { W vs. M } \\
p\end{array}$} \\
\hline & $n=29$ & $n=13$ & $n=16$ & \\
\hline $\begin{array}{l}\text { Age (years) } \\
\mathrm{M} \pm \mathrm{SD}\end{array}$ & $62.5 \pm 7.9$ & $64.4 \pm 6.7$ & $60.9 \pm 8.7$ & 0.252 \\
\hline $\begin{array}{l}\mathrm{BMI}\left(\mathrm{kg} / \mathrm{m}^{2}\right) \\
\mathrm{M} \pm \mathrm{SD}\end{array}$ & $33.4 \pm 3.1$ & $33.5 \pm 3.4$ & $33.3 \pm 2.9$ & 0.866 \\
\hline $\begin{array}{l}\text { COPD duration (years) } \\
\mathrm{M} \pm \mathrm{SD}\end{array}$ & $8.3 \pm 5.2$ & $9.0 \pm 5.5$ & $7.8 \pm 5.0$ & 0.528 \\
\hline $\begin{array}{l}\text { COPD exacerbation (number/year) } \\
M \pm S D\end{array}$ & $1.1 \pm 0.9$ & $1.3 \pm 0.8$ & $1.1 \pm 0.7$ & 0.275 \\
\hline $\begin{array}{c}\text { Pack-year } \\
M \pm S D\end{array}$ & $44.7 \pm 19.0$ & $41.8 \pm 14.8$ & $47.1 \pm 22.0$ & 0.471 \\
\hline $\begin{array}{l}\text { CAT (points) } \\
\mathrm{M} \pm \mathrm{SD}\end{array}$ & $18.9 \pm 5.4$ & $19.1 \pm 3.9$ & $18.8 \pm 5.1$ & 0.817 \\
\hline $\begin{array}{l}\mathrm{FEV}_{1}(\% \text { of normal }) \\
\mathrm{M} \pm \mathrm{SD}\end{array}$ & $52.9 \pm 14.9$ & $52.8 \pm 13.6$ & $53.0 \pm 16.3$ & 0.979 \\
\hline
\end{tabular}




\begin{tabular}{|c|c|c|c|c|}
\hline \multirow[t]{2}{*}{ Parameter } & Total & $\begin{array}{l}\mathrm{A} \\
\mathrm{BMI} \leq 30\end{array}$ & $\begin{array}{l}\mathrm{A} 1 \\
\mathrm{BMI}>30\end{array}$ & \multirow[t]{2}{*}{$\begin{array}{l}\text { Test } \\
p\end{array}$} \\
\hline & $n=72$ & $n=44$ & $n=28$ & \\
\hline $\begin{array}{l}\text { Sex: } \\
\text { Women } \\
\text { Men }\end{array}$ & $\begin{array}{l}38(52.8 \%) \\
34(47.2 \%)\end{array}$ & $\begin{array}{l}20(45.4 \%) \\
24(54.6 \%)\end{array}$ & $\begin{array}{l}18(64.3 \%) \\
10(35.7 \%) \\
\end{array}$ & 0.187 \\
\hline $\begin{array}{l}\text { Age (years) } \\
M \pm S D\end{array}$ & $51.7 \pm 12.4$ & $51.3 \pm 12.2$ & $52.3 \pm 12.8$ & 0.745 \\
\hline $\begin{array}{l}\text { Asthma duration }<\mathrm{t} 0 />\text { (years) } \\
\mathrm{M} \pm \mathrm{SD}\end{array}$ & $19.6 \pm 11.0$ & $20.0 \pm 12.1$ & $19.1 \pm 9.3$ & 0.736 \\
\hline $\begin{array}{l}\text { Asthma exacerbation (number/year) } \\
\quad \mathrm{M} \pm \mathrm{SD}\end{array}$ & $1.5 \pm 0.9$ & $1.3 \pm 0.7$ & $1.9 \pm 1.1$ & 0.010 \\
\hline $\begin{array}{l}\text { ACQ (points) } \\
M \pm S D\end{array}$ & $2.57 \pm 0.70$ & $2.59 \pm 0.81$ & $2.54 \pm 0.51$ & 0.758 \\
\hline $\begin{array}{l}\mathrm{FEV}_{1}(\% \text { of normal }) \\
\mathrm{M} \pm \mathrm{SD}\end{array}$ & $65.2 \pm 16.1$ & $66.1 \pm 16.4$ & $63.6 \pm 15.8$ & 0.530 \\
\hline
\end{tabular}

\begin{tabular}{|c|c|c|c|c|}
\hline \multirow[t]{2}{*}{ Parameter } & Total & $\begin{array}{l}\mathrm{B} \\
\mathrm{BMI} \leq 30 \\
\end{array}$ & $\begin{array}{l}\text { B1 } \\
\text { BMI > } 30 \\
\end{array}$ & \multirow[t]{2}{*}{$\begin{array}{l}\text { Test } \\
p\end{array}$} \\
\hline & $n=79$ & $n=50$ & $n=29$ & \\
\hline $\begin{array}{l}\text { Sex: } \\
\text { Women } \\
\text { Men }\end{array}$ & $\begin{array}{l}34(43.0 \%) \\
45(57.0 \%)\end{array}$ & $\begin{array}{l}13(44.8 \%) \\
16(55.2 \%)\end{array}$ & $\begin{array}{l}21(42.0 \%) \\
29(58.0 \%)\end{array}$ & 0.993 \\
\hline $\begin{array}{c}\text { Age (years) } \\
M \pm S D\end{array}$ & $66.2 \pm 8.3$ & $62.5 \pm 7.9$ & $68.3 \pm 7.8$ & 0.002 \\
\hline $\begin{array}{l}\text { COPD duration (years) } \\
\mathrm{M} \pm \mathrm{SD}\end{array}$ & $8.7 \pm 6.5$ & $9.0 \pm 7.2$ & $8.3 \pm 5.2$ & 0.651 \\
\hline $\begin{array}{l}\text { COPD exacerbation (number/year) } \\
\mathrm{M} \pm \mathrm{SD}\end{array}$ & $1.1 \pm 0.7$ & $1.1 \pm 0.7$ & $1.1 \pm 0.7$ & 0.729 \\
\hline $\begin{array}{c}\text { Pack-year } \\
M \pm S D\end{array}$ & $43.4 \pm 15.9$ & $42.6 \pm 14.0$ & $44.7 \pm 19.0$ & 0.574 \\
\hline CAT (points) & & & & 0.345 \\
\hline $\begin{array}{l}\mathrm{FEV}_{1}(\% \text { of normal }) \\
\mathrm{M} \pm \mathrm{SD}\end{array}$ & $54.0 \pm 13.2$ & $54.6 \pm 12.3$ & $52.9 \pm 14.9$ & 0.588 \\
\hline
\end{tabular}

\section{Discussion}

The negative influence of obesity on asthma is complex. In obese patients an increase in serum leptin level is a proinflammatory factor that increases bronchial hyper-responsiveness, and decreases concentrations of adiponectin and adipokines, which have an antiinflammatory effect by blocking the activity of numerous proinflammatory cytokines, such as: IL-6, TNF- $\alpha$ and NF- $\kappa B$ [6]. The mechanical effect of obesity is of little meaning. Concomitant diseases such as esophageal reflux disease, sleep apnea, and diabetes were more important [7]. The significant increase in the number of exacerbations in this group confirms that obesity exerts a negative influence on the course of asthma. Frequency analysis of the concomitant diseases in the evaluated group revealed that esophageal reflux disease was diagnosed without performing any diagnostics, and sleep apnea was not diagnosed at all.
In the group with severe COPD, obesity decreases the risk of mortality (the so-called obesity paradox) [13]. This phenomenon has not yet been explained. Probably, adipose tissue-free body mass, higher in obese patients (phenotype 2 ) than in cachectic patients (phenotype 1), plays a significant role. In the evaluated group the exacerbation frequency was not increased in comparison to the patients with $\mathrm{BMI} \leq$ 30 , which proves that obesity is not one of the risk factors for worsening of the COPD course. At the same time, the COPD patients live longer, which increases the risk of obesity (visible in group B1).

\section{Conclusion}

Less effective control of asthma in obese patients correlates with the female sex. Age constitutes a risk factor for obesity in patients with COPD.

Source of funding: This work was funded by the authors' resources. Conflict of interest: The authors declare no conflict of interests. 


\section{References}

1. Akinbami LJ, Moormon JE, Bailey C, et al. Trends in asthma prevalence, health care use and mortality in the United States, 2001-2010. NCHS Bata Brief 2012; 94: 1-8.

2. Ogden CL, Caroll MD, Kit BK, et al. Prevalence of obesity among older adults in the United States, 2007-2010. NCHS Data Brief 2013; 131: 1-8.

3. World Health Organisation. Obesity. Geneva: WHO; 2008. Avaible from URL: http://www.who.int/topics/obesity/en.

4. Global Initiative for Asthma. Global strategy for asthma management and prevention 2014 [cited 15.03.2016]. Avaible from URL: www.ginaasthma.com.

5. Stream AR, Sutherland ER. Obesity and asthma disease phenotypes. Curr Opin Allergy Clin Immunol 2012; 12(1): 76-81.

6. Boulet LP. Asthma and obesity. Clin Exp Allergy 2012; 43(1): 8-21.

7. Bruno A, Pace E, Cibella F, et al. Body Mass Index and comorbidities in adult severe asthmatics. Biomed Res Int 2014; 2014: 607192.

8. Dunn RM, Lehman E, Chinchilli VM, et al. Impact of Age and Gender on Response to Asthma Therapy. Am J Respir Crit Care Med 2015; 192(5): 511-518.

9. Global Strategy for Diagnosis, Management and Prevention of COPD. Updated 2014 [cited DATA 15.03.2016]. Avaible from URL: www.goldcopd.org.

10. Foreman MG, Zhang L, Murphy J, et al. Early-onset chronic obstructive pulmonary disease is associated with female sex, maternal factors, and African American race in the COPD Gene study. Am J Respir Crit Care Med 2011; 184(4): 414-420.

11. Pinto LM, Alghamdi M, Benedetti A, et al. Derivation and validation of clinical phenotypes for COPD: a systematic review. Respir Rev 2015; 16: 50, doi: 10.1186/s12931-015-0208-4.

12. Hanania NA, Mullerova $\mathrm{H}$, Locantore NW, et al. Determinants of depression in the ECLIPSE chronic obstructive pulmonary disease cohort. Am J Respir Crit Care Med 2011; 183(5): 604-611.

13. Landbo $C$, Prescott $\mathrm{E}$, Lange $\mathrm{P}$, et al. Prognostic value of nutritional status in chronic obstructive disease. Am J Respir Crit Care Med 1999; 160(6): 1855-1861.

14. Watson L, Vonk JM, Lofdahl CG, et al. Predictors of lung function and its decline in mild to moderate COPD in association with gender: results from the Euroscop study. Respir Med 2006; 100(4): 746-753.

15. Juniper EF, Svensson K, Mork A-C, et al. Measurement properties and interpretation of three shortened versions of the asthma control questionnaire. Respir Med 2005(5); 99: 553-558.

16. Jones PW, Harding G, Berry P, et al. Development and first validation of the COPD Assesment Test. Eur Respir J 2009; 34(3): 648-654.

Address for correspondence:

Krzysztof Wytrychowski, MD, PhD

Katedra i Klinika Chorób Wewnętrznych i Alergologii UM

ul. Skłodowskiej-Curie 66

50-369 Wrocław

Polska

Tel.: +48 71 784-25-21

E-mail: krzysztof.wytrychowski@umed.wroc.pl

Received: 30.03.2016

Revised: 12.04 .2016

Accepted: 28.04.2016 